\title{
PENINGKATAN KEMAMPUAN MEMBACA PERMULAAN MELALUI PENDEKATAN WHOLE LANGUAGE
}

FAHRURROZI

\author{
Prodi PGSD Fakultas Ilmu Pendidikan Universitas Negeri Jakarta \\ Email: fahrurrozi_unj@yahoo.com
}

\begin{abstract}
The purpose of this study was to obtain empirical data about the increased ability of one grade student' reading at SDN Kramat Pela 07 Pagi Jakarta Selatan, using the whole language. The research was conducted at SDN Kramat Pela 07 Pagi Jakarta Selatan to the subject of research is the one grade students, amounting 30 studens in the first semester of academic year 2014/2015. Classroom action research was conducted using a cycle of John Elliot. Classroom action research conducted through the stages of planning, implementation actions, monitoring/observation, of reflection and evaluation as a basis for re-planning of each subsequent cycle. The research was carried out as much as 2 cycles where each cycle consists of $3 \times$ meetings with each meeting time allocation of $2 \times 35$ minutes. The results obtained from student evaluations at each cycle are as follows: I cycle $53 \%$ of students who have reached the score of 75, whereas in cycle 2 there was an increase to $100 \%$ of students who have reached the score of 75. The implications of this research is the use of whole language can be one of alternative menthods to improve student' reading grade I at SDN Kramat Pela 07 Pagi Jakarta Selatan.
\end{abstract}

Keywords : reading ability and whole language

\begin{abstract}
Abstrak: Tujuan penelitian ini adalah untuk memperoleh data empirik tentang peningkatan kemampuan membaca permulaan siswa kelas I SDN Kramat Pela 07 Pagi Jakarta Selatan melalui pendekatan whole language. Penelitian ini dilakukan di SDN Kramat Pela 07 Pagi Jakarta Selatan dengan subyek peneliti adalah siswa kelas I yang berjumlah 30 siswa pada semester I tahun ajaran 2014/2015. Penelitian tindakan kelas ini dilaksanakan dengan menggunakan siklus dari John Elliot. Penelitian tindakan kelas dilakukan melalui tahapan perencanaan, pelaksanaan tindakan, pemantauan/observasi, pemberian refleksi dan evaluasi sebagai dasar untuk membuat perencanaan ulang setiap siklus berikutnya. Penelitian ini dilaksanakan sebanyak 2 siklus dimana tiap siklusnya terdiri dari 3 kali pertemuan dengan alokasi waktu tiap pertemuannya 2 × 35 menit. Hasil yang diperoleh dari evaluasi siswa pada setiap siklusnya adalah sebagai berikut: siklus I 53,3\% dari siswa yang sudah mencapai skor 75, sedangkan pada siklus II terjadi peningkatan menjadi $100 \%$ dari siswa sudah mencapai skor 75. Implikasi penelitian ini adalah penggunaan pendekatan whole language dapat dijadikan salah satu alternatif pendekatan untuk meningkatkan kemampuan membaca permulaan siswa kelas I SDN Kramat Pela 07 Pagi Jakarta Selatan.
\end{abstract}

Kata kunci: kemampuan membaca permulaan,-pendekatan whole language

Pengajaran bahasa Indonesia

di sekolah dasar (SD) yang memegang peran penting adalah salah

satunya membaca,

pembelajaran membaca di SD meliputi pembelajaran membaca permulaan dan pembelajaran membaca lanjutan. Dewasa ini 
pembelajaran membaca permulaan belum optimal dilakukan dengan baik di SD. Hal ini sejalan dengan apa yang dikemukakan oleh Muslich (2008) yang menyatakan pembelajaran membaca permulaan perlu disampaikan sejak usia dini hal bertolak dari kenyataan bahwa masih terdapat sebelas juta anak Indonesia dengan usia $7-8$ tahun tercatat masih buta huruf. Selain itu, menurut laporan program pembangunan 2005 PBB tentang daftar negara berdasarkan tingkat melek huruf, Indonesia masih berada pada peringkat 95 dari 175 negara.

Selain itu berangkat dari kenyataan di atas, di SD-SD ditemukan kesulitan yang dihadapi oleh siswa dalam membaca permulaan diantaranya belum lancar membaca kata dan kalimat, belum lancar membaca nyaring huruf, kata, kalimat dengan lafal dan intonasi yang benar. Selain itu, siswa cenderung membaca buku bila diperintah oleh guru dan saat jam pelajaran berlangsung. Berikutnya belum ada kesadaran sendiri dari siswa untuk melakukan membaca dan hanya beberapa siswa yang memanfaatkan waktu istirahatnya untuk belajar membaca buku, walaupun itu hanya buku cerita. Mereka lebih senang memanfaatkan waktu luangnya untuk bermain. Namun, hal tersebut bukanlah salah siswa sepenuhnya, karena fasilitas dan sarana sekolah atau kelas yang kurang menunjang sehingga rangsangan untuk membuat anak tertarik membaca pun kurang. Bila anak memiliki minat membaca yang tinggi, ia akan selalu meluangkan waktu beberapa jam dalam sehari untuk membaca. Setidaknya ia tidak akan pernah terlepas dari media cetak untuk mengisi hari-harinya.

Dalam pembelajaran bahasa hendaknya disajikan secara holistik dengan memadukan keempat keterampilan berbahasa tersebut agar pembelajaran lebih bermakna bagi siswa. Siswapun akan merasa apa yang dipelajari akan selalu berkesinambungan dan termotivasi mengikuti pelajaran. Guru sebagai pendidik yang berperan didalam kelas diharapkan mampu memilih cara yang efektif dalam mengajarkan pembelajaran bahasa secara holisik. Selain itu, guru juga diharapkan 
dapat menciptakan suasana yang kondusif dalam kelas, sehingga anak lebih terarah untuk membaca dan merasa nyaman selama belajar.

Berdasarkan observasi hasil yang dilakukan peneliti, tidak semua siswa kelas I SDN Kramat Pela 07 Pagi Jakarta Selatan mempunyai kemampuan membaca permulaan (membaca nyaring) yang baik. Berdasarkan observasi awal terhadap 30 siswa kelas I SDN Kramat Pela 07 Pagi Jakarta Selatan, diperoleh data sebagai berikut, 1 siswa belum lancar membaca, 13 siswa lancar tapi intonasi kurang tepat, 16 siswa lancar membaca dengan intonasi yang benar. Dari data tersebut dapat diasumsikan kemampuan membaca permulaan siswa kelas I di SDN Kramat Pela 07 Pagi Jakarta Selatan masih rendah.

Banyak faktor yang mendukung faktarendahnya kemampuan membaca permulaan siswa kelas I yaitu: 1) Target KKM 75 belum tercapai 2) Media yang digunakan oleh guru hurufnya berukuran kecil karena diambil langsung dari buku teks, sehingga siswa menjadi kurang semangat untuk membaca, 3) Pembelajaran bahasa kurang berkesinambungan dengan keempat keterampilan berbahasa yaitu mendengarkan, berbicara, membaca dan menulis, sehingga siswa merasa pembelajaran kurang menyenangkan,4) Metode yang digunakan guru kurang membangun motivasi belajar membaca siswa, sehingga anak tidak tertarik mengikuti pelajaran, 4) Siswa memiliki minat yang kurang terhadap aktivitas membaca, sehingga keberhasilan membaca kurang maksimal.

Banyak pendekatan yang bisa dipilih oleh guru untuk menciptakan suasana kelas yang kondusif, sarat dengan bahan bacaan, serta nyaman bagi anak untuk belajar. Salah satu pendekatan yang bisa digunakan guru dalam mengajar adalah pendekatan whole language. Whole language merupakan salah satu pendekatan pengajaran bahasa yang bertujuan menyajikan pengajaran bahasa secara utuh dan tidak terpisah-pisah. Pendekatan ini memberikan berbagai pandangan kepada pembelajar bahwa pembelajaran bahasa dilakukan 
secara terintegratif untuk menumbuhkan lingkungan belajar bahasa yang disukai oleh pembelajaran. Dalam kelas whole language pembelajaran penuh dengan barang cetakan. Kegiatan pembelajaran whole language, siswa belajar melalui model atau conto. Selain itu, siswa bekerja dan belajar sesuai dengan tingkat kemampuannya, siswa berbagi tanggung jawab dalam pembelajaran, siswa terlibat aktif dalam pembelajaran, siswa berani mengambil risiko dan bebas bereksperimen, dan siswa mendapat balikan (feedback) positif baik dari guru maupun temannya.

Berdasarkan uraian di atas, pendekatan whole language merupakan pendekatan yang dapat meningkatkan kemampuan membaca pemulaan siswa kelas I SDN Kramat Pela 07 Pagi Jakarta Selatan. Dengan penerapan pendekatan whole language, diharapkan dapat meningkatkan kemampuan membaca permulaan siswa kelas I SDN Kramat Pela 07 Pagi Jakarta Selatan dalam menyuarakan kalimat sederhana yang dibaca dan dapat memahami isinya dengan baik.

Kemampuan Membaca Permulaan Kegiatan membaca merupakansesuatu yang sulit dan kompleks karena kegiatan membaca tidak hanya melafalkan tulisan, tetapi juga melibatkan aktivitas visual, berpikir, psikolinguistik, dan metakognitif. Menurut Crawley (1995:16) membaca merupakan proses menerjemahkan simbol tulis (huruf) kedalam kata-kata lisan. Dalam kegiatan menterjemahkan huruf ini dapat dilakukan melalui disuarakan dan tidak disuarakan. Kegiatan membaca yang disuarakan bertujuan agar dapat mengenal huruf dan membunyikannya secara tepat sedangkan menterjemahkan huruf terkait dengan kemampuan memahami huruf yang dibaca. Pendapat lain dikemukakan Tarigan (1979: 105) yang menyatakan membaca adalah suatu proses kegiatan mengenal dan memahami simbol-simbol tertulis untuk memperoleh pesan yang disampaikan penulis melalui bahasa tulis. Apabila dimaknai pendapat Tarigan ini membaca merupakan kegiatan yang 
dilakukan oleh seseorang dengan maksud dan tujuan agar dapat memahami secara baik informasi yang didalamnya mencakup isi dan makan dari bacaan tersebut. Ruddell dalam Morrow mendefinisikan membaca sebagai salah satu dari penggunaan berbahasa untuk menguraikan tulisan atau simbol dan memahaminya.

Membaca permulaan ini dapat di berikan atau diajarkan lansung kepada anak yang disesuaikan dengan tahap perkembangan masing-masing anak yang berada di SD kelas awal. Hal ini sesuai dengan Thomson dalam Rahim (37) mengatakan bahwa waktu yang paling tepat untuk mengajarkan anak membaca adalah saat anak-anak duduk di Tanam Kanak-kanak.

\section{Ditambahkan} oleh Dardjowidjoyo (2008:300) untuk memahami adanya keteraturan bentuk huruf anak harus memiliki prasyarat yang bersifat psikologis dan neurologis. Dari segi psikologis, anak harus terlebih dahulu mengembangkan kemampuan kognitifnya sehingga ia dapat membedakan satu bentuk dengan bentuk lainnya. Dengan kemampuan ini, anak dapat memahami bentuk huruf. Prasyarat kognitif lainnya yang harus terlebih dahulu dimiliki anak untuk dapat mengembangkan kemampuan membaca adalah adanya atensi motivasi, kemampuan asosiatif atau kemampuan untuk dapat mengaitkan sesuatu dengan sesuatu yang lain dan kemampuan memaknai simbol. Simbolisasi diperlukan karena anak harus memahami bahwa apa yang selama ini mereka dengar dan ucapkan dalam bentuk bunyi dapat disimbolkan dalam bentuk huruf. Dari segi neurologis, anak tidak akan mungkin dapat mula membaca sebelum neuro-biologinya memungkinkan. Misalnya pada umur satu tahun dimana otak baru berkembang sekitar $60 \%$ dari otak orang dewasa, anak belum dapat mngidentifikasi ltak garis lurus dan setengah lingkaran. (Dardjowidjoyo, 1995:19) Maka anak usia 5-6 tahun telah memiliki prasyarat ini dengan kata lain anak telah memiliki kesiapan belajar membaca.

Sehubungan dengan hal di atas, kegiatan membaca di SD 
khususnya kelas awal diarahkan kepada kemampuan siswa dalam melafalkan huruf ke dalam bunyi yang jelas dan nyaring. Oleh karena itu, kegiatam membaca permulaan merupakan aspek yang sangat penting yang perlu dikuasai sejak dini oleh siswa karena dengan kemampuan sejak dini dalam membaca siswa akan mempu memahami berbagai informasiinformasi dalam berbagai ilmu pengetahuan secara baik dan benar.

Berdasarkan uraian diatas dapat disimpulkan membaca adalah suatu proses untuk memperoleh pesan dari penulis dengan cara menghubungkan simbol-simbol bahasa, mengenali huruf, kata-kata, menghubungkan bunyi serta maknanya dan menarik kesimpulan mengenai maksud bacaan.

\section{Pendekatan Whole Language}

Menurut Goodman (1986) dan Weaver (1992) dalam Zulela (2012:105), whole language adalah pembelajaran bahasa secara utuh, tidak terpisah-pisah. Melalui empat keterampilan berbahasa (membaca, menulis, menyimak, dan berbicara), komponen kebahasaan disajikan secara utuh dalam pembelajaran.

Selanjutnya Meha (2014)

mengatakan Whole language merupakan cara bagaimana anak belajar bahasa, baik lisan maupun tulisan. Anak belajar berbicara, mendengarkan, membaca, dan menulis sesuai dengan perkembangannya.

Brown

memaparkan bahwa pendekatan terpadu menyarankan agar pengajaran bahasa Indonesia didasarkan pada wawasan Whole Language, yaitu wawasan belajar bahasa yang intinya menyarankan agar kegiatan pembelajaran bahasa Indonesia dilaksanakan terpadu antara membaca, mendengarkan, menulis, dan berbicara. Dengan konsep itu, dalam jangka panjang, target penguasaan kemahiran wacana itu bisa tercapai.

Eisele (1991: 29-47) menyatakan bahwa prinsip-prinsip pendekatan whole language sebagai berikut:

1. Anak tumbuh dan belajar lebih siap ketika mereka secara aktif mengajak dirinya sendiri untuk belajar. 
2. Strategi dan kemahiran mereka pada proses kompleks seperti membaca dan menulis namun harus difasilitasi dengan baik oleh guru. Mereka perlu didukung secara psikologi.

3. Untuk membangun munculnya kemampuan membaca dan menulis, siswa perlu mencoba untuk meniru strategi orang tua atau guru

4. Pengajaran dengan whole language didasarkan pada pengamatan bawa banyak hal yang dipelajari pada diri siswa, sehingga guru perlu memberikan kesempatan dan mendorong ke dalam proses belajar.

5. Pembelajaran dengan whole language merangsang siswa untuk belajar secara mandiri. Tugas guru memberikan bimbingan kepada siswa.

6. Guru dan siswa bersama-sama belajar dan mengambil resiko serta mengambil keputusan bersama dalam belajar.

7. Guru mengenalkan interaksi sosial antara siswa, berdiskusi, berbagi ide, bekerja sama untuk menyelesaikan masalah yang dihadapi dalam belajar.

8. Guru memberikan materi kepada siswa berupa tes agar mampu membedakan kemampuan mana yang belum optimal serta mendorong siswa untuk menemukan dan mengkritik kelemahan sendiri.

9. Penilaian disatukan dengan pembelajaran.

10. Guru membangun dan mengembangkan jenis tingkah laku serta sikap yang diperlukan dalam kemajuan belajar siswa.

Dari uraian di atas peneliti dapat menarik kesimpulan bahwa pendekatan whole language merupakan sebuah pendekatan di mana kompetensi-kompetensi berbahasa saling dihubungan disaat pembelajaran berlangsung sehingga di dalam pembelajaran tersebut dapat mencapai tujuan yang telah ditentukan dalam proses belajar mengajar di sekolah secara optimal.

komponen whole language pada anak usia dini sebagai berikut:

1. Welcoming activity : reading aloud of poem, chant, or song, use of enlarged material (printed 
matter large enough for group viewing). Pada kegiatan awal biasanya guru membaca dengan keras puisi, huruf -huruf, atau lagu. Guru menggunakan bahan cetakan yang dapat diperbesar (cetakan dibuat cukup besar agar dapat dilihat dan dibaca oleh siswa dalam kelompok/kelas).

2. Favorite stories : rereading of stories, usually by request, unison participant, discussion of syntax. Guru menyampaikan cerita/dongeng, biasanya cerita yang disajikan sesuai dengan permintaan anak-anak dan disesuaikan dengan tema, lalu anak-anak diskusi bersama tentang kata-kata baru yang ada dalam cerita.

3. Language activity : exploration of language through games, riddles, puzzles. Dalam komponen ini, kegiatan berbahasa dilakukan dengan mengeksplorasi bahasa melalui permainan kata-kata yang hilang atau teka-teki baik dalam kelompok atau berpasangan.

4. New story : introduction of new story for the day, words pointed to as they are read aloud, language experiences shared. Pengenalan cerita baru untuk hari itu dalam kemasan tematik, guru menyuruh anak-anak mengucapkan kata-kata yang ditunjuk lalu membaca keraskeras, mereka dapat belajar bahasa melalui pengalaman membaca bersama.

5. Independent Reading : self selection of old favorites to read, engagement in literary activities of choice. Anak-anak memilih sendiri bahan bacaan yang disukainya layaknya orang dewasa untuk dibaca, mereka mulai menunjukkan keterlibatan dalam kegiatan membaca sastra pilihan.

6. Expression : art and writing activities: group drama. Anakana dapat berekspresi dalam kegiatan tematik dengan menunjukkan hasil kerja berdasarkan apa yang dibaca dan didengarnya dan menulis kegiatan dalam bentuk jurnal atau masuk dalam kelompok drama. 
Beberapa penelitian yang berkaitan dengan tulisan peneliti antara lain : penelitian yang dilakukan oleh Dwi Joko Raharjo dengan skripsi yang berjudul: "Peningkatan

Keterampilan

Membaca melalui Pendekatan Whole Language pada Siswa Kelas I SD negeri 1 Masaran Kabupaten Sragen Tahun Pelajaran 2005/2006". Penelitian tersebut menunjukkan bahwa keterampilan membaca dapat ditingkatkan melalui pendekatan whole language.Penelitian yang lain dilakukan oleh Sutrisno dengan skripsi berjudul: "Peningkatan Kemampuan Membaca Nyaring dengan Menggunakan Pendekatan Whole Language pada Siswa Kelas I SLTP Negeri 1 Wedarijaksana”. Penelitian tersebut menunjukkan bahwa melalui pendekatan whole languagekemampuan membaca nyaring siswa kelas I SLTP Negeri 1 Wedarijaksa mengalami peningkatan.Hasil penelitian relevan yang lain adalah penelitian yang telah dibuat oleh Slamet Edi Priyono pada semester I tahun 2007/2008 dengan judul "Peningkatan Hasil Belajar Bahasa Inggris melalui pendekatan Whole Language pada Siswa kelas IV SDN Cipinang Cempedak 01 Pagi Jakarta Timur".Penelitian tersebut menunjukkan bahwa hasil belajar bahasa Inggris dapat meningkat melalui pendekatan whole language.

\section{METODE PENELITIAN}

Penelitian ini bertujuan untuk mengetahui upaya peningkatan kemampuan membaca permulaan melalui pendekatan whole language pada siswa kelas I SDNKramat Pela 07 Pagi Jakarta Selatan. Penelitian ini dilaksanakan pada siswa kelas 1 SDN Kramat Pela 07 Pagi Jakarta Selatan. Metode penelitian yang digunakan adalah Penelitian Tindakan Kelas (Classroom Action Research) model proses siklus (putaran/spiral) yang mengacu pada model PTK Kemmis dan McTaggart yang dalam satu siklus terdiri dari empat komponen, yaitu: perencanaan (planning), aksi/tindakan (acting), observasi (observing) dan refleksi (reflecting).

\section{HASIL DAN PEMBAHASAN}


Data yang diperoleh berasal dari data pemantau tindakan dan data hasil penelitian. Analisis data pemantau dilakukan dengan melihat interaksi siswa dan guru saat proses pembelajaran. Sedangkan analisis data penelitian berupa penilaian kemampuan membaca permulaan.

\section{Siklus I}

Berdasarkan pengamatan observer, terlihat peneliti terburu buru dalam proses pembelajaran seperti memberikan petunjuk, membantu siswa menemukan apa yang ingin ditulisnya, membantu siswa untuk menulis dengan benar, memberi kesempatan kepada siswa untuk berdiskusi, memberi kesempatan kepada siswa untuk memilih bacaan yang mereka sukai, sehingga siswa kurang memahami apa yang disampaikan peneliti. Peneliti juga kurang memberikan kesempatan kepada siswa untuk membaca secara bergiliran.

Selain itu peneliti juga kurang memotivasi siswa agar lebih aktif selama proses pembelajaran berlangsung. Hal ini dikuatirkan bahwa potensi yang dimiliki siswa tidak berkembang secara optimal dan berdampak pada hasil evaluasi yang hasil target belum mencapai tidak mendapatkan nilai sesuai yang ditargetkan yakni $75 \%$ dari jumlah siswa mendapat nilai di atas 75 .

\section{Siklus II}

Pada siklus ini peneliti memperbaiki kekurangankekurangan yang terjadi pada siklus I. Hal ini terlihat dari sikap peneliti yang lebih tenang dan tidak terburuburu dalam melaksanakan pembelajaran. Selain itu peneliti juga telah menyediakan berbagai macam bacaan yang menarik sehingga memancing motivasi anak untuk membaca. Dan siswa boleh memilih mana yang ingin ditulisnya. Sehingga mereka bersemangat untuk belajar karena termotivasi dari diri sendiri bukan semata-mata perintah dari orang lain. Dan peneliti pun selalu memberi bimbingan serta memberikan penguatan.

Siswa secara keseluruhan juga terlihat sudah dapat membaca dengan menggunakan pendekatan whole language dengan baik dan terlibat secara aktif dalam pembelajaran, sehingga hasil evaluasi yang diharapkan dapat 
Peningkatan Kemampuan Membaca...

Fahrurrozi

tercapai yakni $75 \%$ dari jumlah siswa telah mencapai skor di atas 75 .

Data pemantau tindakan dalam pembelajaran meliputi 20 pernyataan seperti yang tertuang dalam instrumen data pemantau tindakan dengan nilai yang diharapkan mencapai nilai 70 pada setiap akhir siklusnya. Adapun hasilnya adalah sebagai berikut:

Tabel 2

Nilai Data Pemantau Interaksi Siswa dan Guru

\begin{tabular}{lll}
\hline Data Pemantau & \multicolumn{2}{c}{ Nilai Akhir } \\
\cline { 2 - 3 } & Siklus I & Siklus II \\
\hline Interaksi siswa dan & 67,5 & 86,2 \\
guru & & \\
\hline
\end{tabular}

Berdasarkan data diatas, guru adalah 86,2. Berikut adalah data pemantau tindakan pada grafik nilai data pemantau siklus I, nilai akhir interaksi siswa tindakan membaca permulaan dan guru adalah 67,5 sedangkan melalui pendekatan whole data pemantau tindakan siklus II, language.

nilai akhir interaksi siswa dan

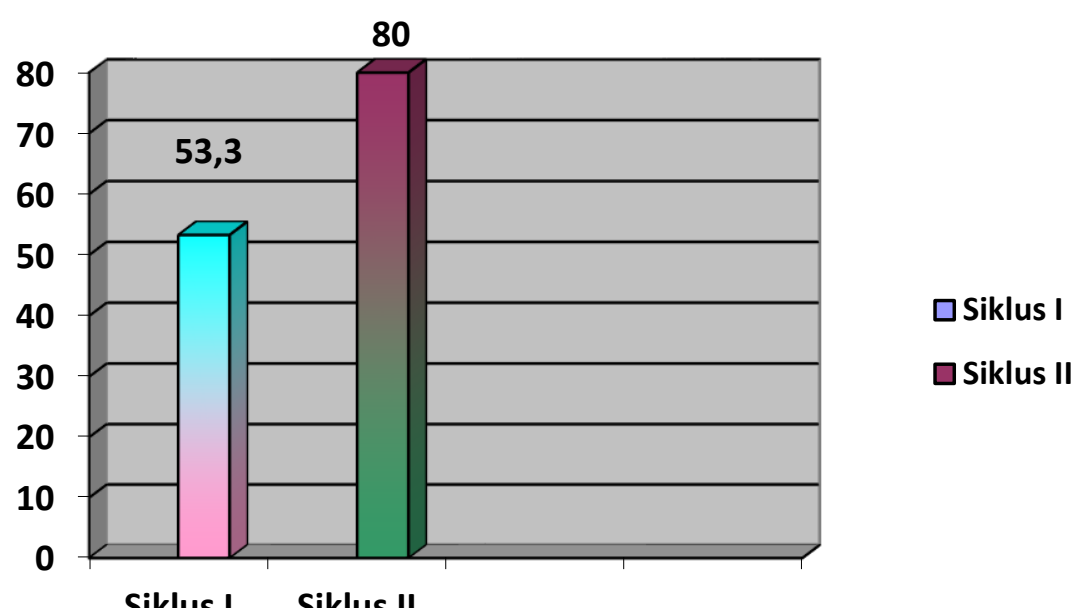

\section{Grafik 1}

Nilai data pemantau tindakan dengan menggunakan metode whole language 
Data hasil penelitian ini diperoleh dari hasil 30 siswa kelas I SDN Kramat Pela 07 Pagi Jakarta Selatan. Kriteria keberhasilan dari hasil belajar pada penelitian ini adalah apabila dalam siklus $75 \%$ dari jumlah siswa telah mencapai skor diatas 75 .

$$
\text { Berdasarkan data hasil }
$$
penilaian kemampuan membaca permulaan siswa dianalisis, kemudian dilakukan penafsiran dengan menggunakan kategori sebagai berikut : a. Kategori rendah, jika tingkat kemampuan siswa antara $55-70$

b. Kategori sedang, jika tingkat kemampuan siswa antara $71-85$

c. Kategori tinggi, jika tingkat kemampuan siswa antara 86 100

Setelah mengetahui tingkat kemampuan siswa, maka dilakukan pengelompokan sehingga dapat diketahui kategori siswa dengan tingkat kemampuan siswa melalui penghitungan sebagai berikut :

Kategori kemampuan siswa $=$
$\frac{\text { Jumlah tingkat kemampuan siswa }}{\text { Jumlah siswa keseluruhan }} \quad$ X 100\%

Hasil dari evaluasi kemampuan membaca permulaan Pada siklus II skor lebih dari siswa yang didapat pada siklus I 75 dengan persentase $80 \%$ dari 30 adalah skor lebih dari 75 dengan persentase 53,3 \% dari 30 siswa diketahui 1 siswa yang mendapat kategori tinggi dengan persentase 3,3 $\%, 15$ siswa yang mendapat kategori sedang dengan persentase $50 \%, 14$ siswa yang mendapat kategori rendah dengan persentase $46,7 \%$. siswa diketahui 13 siswa yang
mendapat kategori tinggi dengan
persentase $43,3 \%, 17$ siswa yang
mendapat kategori sedang dengan
persentase $56,7 \%, 0$ siswa yang
mendapat kategori rendah dengan
persentase $0 \%$.
Berikut adalah grafik hasil
penilaian kemampuan membaca
permulaan siswa pada siklus I dan 
Peningkatan Kemampuan Membaca... Fahrurrozi

siklus II berdasarkan aspek kemampuan membaca permulaan.

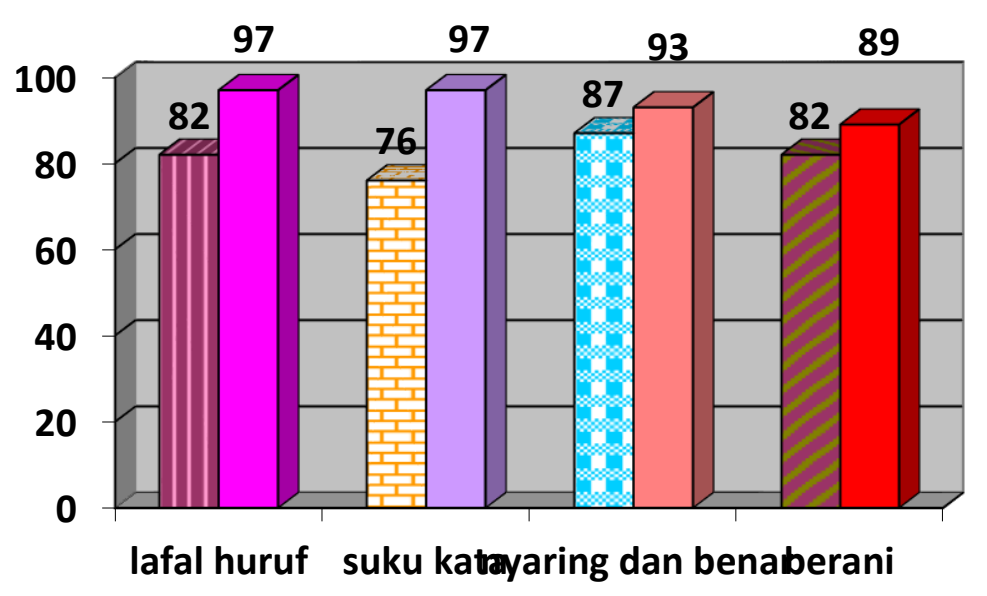

Grafik 2

Kemampuan Membaca Permulaan Siklus I dan Siklus II Berdasarkan aspek Membaca Permulaan

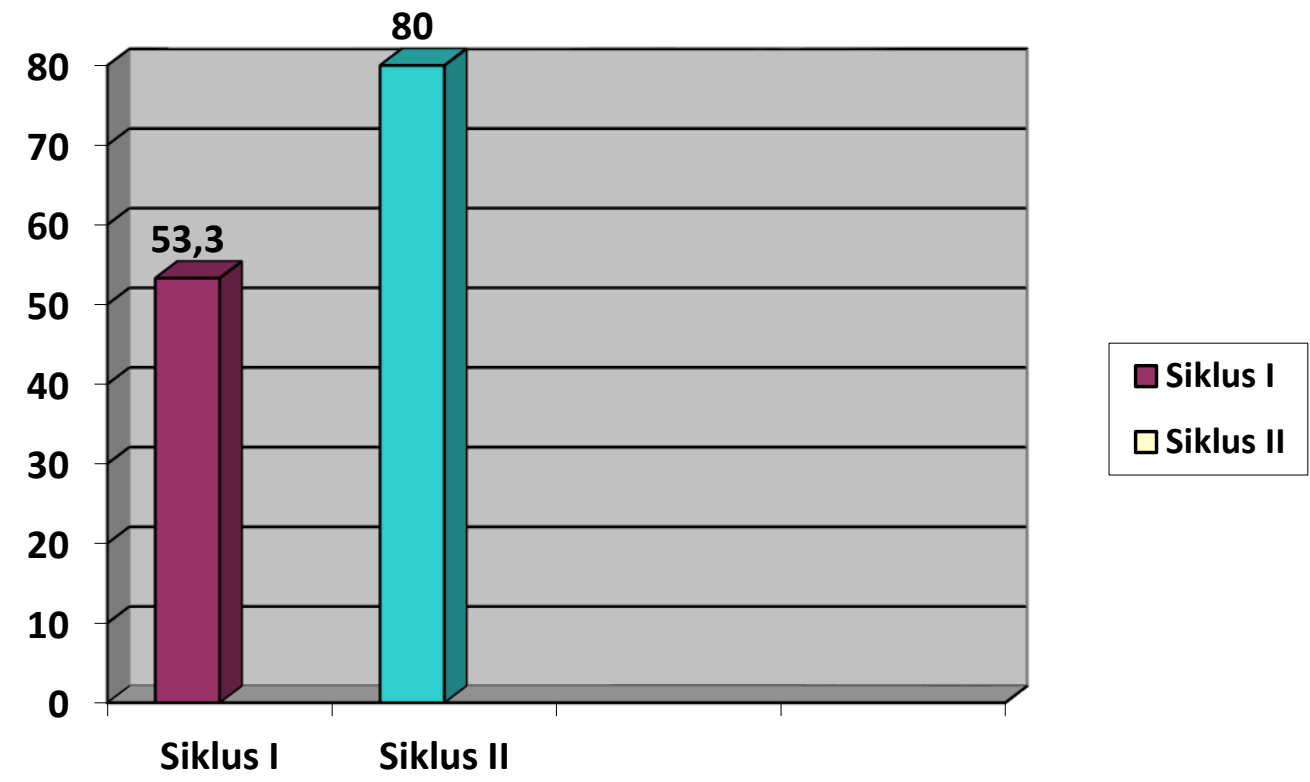

Grafik 3

Hasil Penilaian Kemampuan Membaca Permulaan

Hasil evaluasi pada siklus I yang ditentukan oleh peneliti belum mencapai standar keberhasilan sehingga perlu dilaksanakan siklus II 
dengan perbaikan proses pembelajaran dari sebelumnya agar dapat meningkatkan kemampuan membaca permulaan siswa. Pada siklus II hasil yang diperoleh sudah mencapai standar keberhasilan yang ditentukan oleh peneliti oleh sebab itu peneliti tidak melanjutkan ke siklus III.

Berdasarkan hasil data yang diperoleh pada tindakan pembelajaran membaca permulaan melalui pendekatan whole language telah menunjukkan adanya peningkatan. Pencapaian kemampuan membaca permulaan siswa kelas I SDN Kramat Pela 07 Pagi Jakarta Selatan menunjukkan adanya peningkatan skor diatas 75 yakni pada siklus I sebesar 53,3\% menjadi $80 \%$ pada siklus II.Untuk pemantau tindakan selama proses pembelajaran juga mengalami peningkatan yang signifikan. Pada siklus I interaksi siswa dan guru mencapai nilai 67,5 menjadi 86,2 pada siklus II.

Melihat hasil yang dicapai tersebut membuktikan bahwa pendekatan yang digunakan peneliti untuk meningkatkan kemampuan membaca permulaan siswa dikelas I Sekolah Dasar sudah tepat dan berhasil. Hal tersebut dibuktikan dengan adanya peningkatan nilai rata-rata kelas pada setiap siklus pembelajaran. Implementasi data pendekatan tersebut tidak lepas dari upaya guru yang bertindak sebagai peneliti dalam mengembangkan inovasi dan kreatifitas dalam pembelajaran.

\section{SIMPULAN}

Berdasarkan hasil penelitian dan pembahasan di atas dapat disimpulkan bahwa :

1. Kemampuan membaca permulaan melalui pendekatan whole language kelas I SDN Kramat Pela 07 Pagi Jakarta Selatan, menunjukkan peningkatan hasil belajar dari perolehan skor di atas 75 sebesar 53,3\% dari jumlah siswa pada siklus I menjadi $80 \%$ dari jumlah siswa pada siklus II. Dan data pemantau tindakan pada siklus I, nilai akhir interaksi siswa dan guru adalah 67,5 sedangkan data pemantau tindakan siklus II, nilai akhir interaksi siswa dan guru adalah 86,2 . 
2. Penggunaan pendekatan whole language dalam pembelajaran Bahasa Indonesia khususnya pada aspek membaca memudahkan siswa dalam membaca.

3. Dengan menggunakan metode whole language merupakan salah satu strategi yang tepat digunakan untuk meningkatkan hasil belajar dan kualitas pembelajaran membacanyaring bagi siswa sekolah dasar khususnya kelas rendah.

4. Pembiasaan penggunaan pendekatan whole language dalam proses pembelajaran khususnya pada pelajaran bahasa Indonesia aspek membaca oleh guru dan siswa berpengaruh terhadap hasil yang diinginkan. Apabila guru dan siswa terlatih membaca menggunakan pendekatan whole language hasil yang diharapkan dapat tercapai secara optimal.

\section{DAFTAR PUSTAKA}

Brown, H.D. Principles of Language Learning and Teaching. London: Prentice- Hall International Limited, 1997.
Crawley, S.J and Mountain L, Strategies for Guiding Content Reading, Boston: Allyn and Bacon, 1995.

Dardjowidjoyo,

Soenjono, Psikolinguistik, Jakarta: Yayasan Obor Indonesia, 2008.

Dardjowijojo, Soenjono, "Peran Metode dalam Pengajaran Bahasa," makalah dalam Rangka Dies Natalis ke-41, IKIP Bandung, 1995.

Dwi Joko Raharjo, Peningkatan Kemampuan Membaca melalui Pendekatan Whole Language pada Siswa Kelas I SD Negeri Masaran Kabupaten Sragen Tahun Pelajaran 2005/2006 (Semarang: Skripsi, Universitas Negeri Semarang. 2005).

Eisele, Beverly. Managing the Whole Language Classroom, Creative Teaching Press, Inc., Cypress.1991.

Masnur, Muslich, Upaya Peningkatan Kemampuan Membaca, 2008 (http://ptk.blogspot.com).

Morrow, Lesley Mandel, Literacy Development in the Early Years, United State of America:Allyn and Bacon, 1993.

Nehru Meha dan Adiyati Fathu Roshonah. Implementasi Whole Language Approach Sebagai

Pengembangan Model Pembelajaran Berbahasa Awal Anak Usia 5-6 Tahun Dl Paud Non Formal. . (2014)Diakses pada tanggal 20 September 2015, h. 5.

Slamet Edi Priyono, "Peningkatan Hasil Belajar Bahasa 
JURNAL PENDIDIKAN USIA DINI

Volume 11 Edisi 1, April 2017

Inggris melalui Pendekatan

Whole Language pada

Siswa Kelas IV SDN

Cipinang Cempedak 01

Pagi Jakarta Timur",

Skripsi (Jakarta: Fakultas

Ilmu Pendidikan, UNJ,

2007)

Sutrisno, "Peningkatan Kemampuan

Membaca Nyaring dengan

Menggunakan Pendekatan

Whole Language pada

Siswa Kelas I SLTP Negeri

1 Wedarijaksana". (Bekasi:

Skripsi, 2000).

Tarigan, Henry Guntur, Membaca

Sebagai Suatu

Keterampilan Berbahasa,

Bandung; Angkasa, 1979.

Zulela. Pembelajaran Bahasa

Indonesia : Apresiasi

Sastra di Sekolah Dasar.

Jakarta: Remaja

Rosdakarya. 2012. 